time the application is made. Effectiveness in codling moth control rapidly decreases at the end of twenty days. Egg hatching activity, on the other hand, under normal conditions, is usually approaching its height ten to twelve days following the hatching of the first eggs. At this time, then, a maximum need for protection is demanded and the effectiveness of the application of spray is rapidly decreasing. A large percentage of the losses that result and poor control obtained on the part of orchardists can be traced to this source.

The reduction of time of application of a spray to the shortest safe period preceding egg hatching will only be productive of good results. Very close timing, in the case of protracted egg hatching, will often save an extra application of spray and much unnecessary expense. To accomplish this end it is necessary to obtain a very intimate knowledge of the insect's seasonal behavior and demands a careful investigation in the different sections by a thoroughly competent investigator.

It is the belief of the writer that the losses due to the activities of the codling moth in the Northwest can only be reduced to the minimum through the establishment of observation stations in the widely separated apple growing sections. An investigator located in some of these sections during the past year could have saved his community enough to maintain a station for at least twenty-five years.

\title{
SOME FACTORS INFLUENCING THE DISTRIBUTION OF PEMPHIGUS BET E DOANE IN BEET FIELDS
}

By Asa C. Maxson, In charge of Insect Investigation, The Great Western Sugar Co., Longmont, Colo.

The sugar beet root-louse, Pemphigus betce Doane, presents one of the most serious insect problems which confront the beet sugar industry of the Western States.

The seriousness of this insect's injury immediately becomes apparent when we realize that the difference between the sugar actually produced and what could be produced from the same acreage, were it possible to prevent this injury, amounts to a loss of several hundred thousand dollars annually to the industry.

In the course of his work with this insect, the writer has been continually impressed by the fact that our knowledge of the factors operative in its dispersion and distribution in the sugar beet growing areas of the west is altogether inadequate. This led to the making of a preliminary field survey during the growing season of 1916, it being hoped that something might be learned that would eventually result in the develop- 
ment of better means of controlling this pest than we have at the present time.

This work was undertaken for the express purpose of studying the relation of previous crops and the presence of the winter host tree, Populus angustifolia, to the degree of infestation.

The areas covered will be known in this report as the Longmont and Eaton territories. The former extended from the foothills of the Rocky Mountains, in Boulder County, eastward a distance of 18 miles, contained 44,800 acres and 410 beet fields. The latter, which is in Weld County, was 14 miles long, lay parallel to the mountains with its western boundary 24 miles to the east of them. This territory contained 32,000 acres and 253 beet fields.

Owing to the topography of the country and the shape of the beet growing areas these territories are naturally divided into sections. The Longmont territory is divided into 3 sections. What will be known as the river'section is the most westerly and extends in a narrow strip each side of the St. Vrain River from the foothills to the city of Longmont, a distance of 9 miles. Northeast of this is the central section, a rectangular area 4 miles east and west and 5 miles north and south. East and a little north of the central section is the eastern section. This is also a rectangular area. It is $5 \times 6$ miles, the 6 -mile side running east and west.

The Eaton territory is divided into a north and a south section. The former lies north and west of the town of Eaton. It is rather irregular in shape, being 8 miles north and south with an average width of 3.5 miles. The latter lies south and east of Eaton. North and south it is 6 miles and has an average width of 3.75 miles.

As already stated, the main object in making this survey was to study the relation of previous crops and the presence of the winter host to the degree of infestation. However, it was found that another factor would have to be taken into account in working up the results of the survey, $i$. e., what the writer calls the "time factor." The effect of this and the "previous crop" and "winter host" factors will be considered in the following pages.

The Time Factor.-There is no doubt that the original infestation in all beet fields is due either to the hibernating, wingless lice or the spring migrants which come from the winter host. This being the case, the number of infested beets should not change after migration from the trees ceases (which is about August 1 at the latest with us), unless the lice migrate from beet to beet in the field. That this actually takes place is shown by the following observations.

An examination of several beet fields during August and September revealed many wingless lice and pupæ leaving the soil, climbing up the 
leaf stems and crawling about on the surface of the ground. This was especially noticeable after the beets had been irrigated. The wetting of the lower levels apparently drove the lice to the surface. During their wanderings many became located on beets which were uninfested up to this time.

In order to ascertain to what degree the infestation increased, 300 beets were pulled once a week from a small plot in the experimental field at Longmont and a record made of the number infested. The first 300 were pulled on August 12, at which time 68 beets out of every 100 were infested. One week later the infestation had reached 75 per cent. By the end of the next week 100 per cent were infested.

The action of this factor makes it impossible to make some very desirable comparisons; however, the survey was made in such a way that many interesting comparisons are possible:

The Previous Crop Factor.-The fact that rotation is of little or no value in the control of the sugar beet root-louse has long been apparent. The results of this survey seem to prove quite conclusively that rotation is of no value as a means of reducing the losses due to this insect.

In the following tables all fields in the Longmont and Eaton territories are arranged according to the previous crop.

\begin{tabular}{|c|c|}
\hline \multicolumn{2}{|c|}{ Longmont TerRitory } \\
\hline $\begin{array}{l}\text { Previous Crop } \\
\text { Beets } \\
\text { All grains } \\
\text { Alfalfa } \\
\text { Mixed crops }\end{array}$ & $\begin{array}{c}\text { Per Cent Infestation } \\
85.70 \\
82.31 \\
82.09 \\
78.71\end{array}$ \\
\hline \multicolumn{2}{|c|}{ EAton Territory } \\
\hline $\begin{array}{l}\text { Previous Crop } \\
\text { Potato } \\
\text { Alfalfa } \\
\text { Mixed } \\
\text { Beets } \\
\text { All grains }\end{array}$ & $\begin{array}{c}\text { Per cent Infestation } \\
89.6 \\
83.7 \\
82.4 \\
81.0 \\
79.5\end{array}$ \\
\hline
\end{tabular}

A comparison of these tables reveals the fact that the different crops do not hold the same relative place in the two territories. This would appear to more fully prove the correctness of the statement already made that rotation has little if any value as a control for this insect.

The Winter Host Factor.- - This of all the factors thus far studied appears to be the most active in the spreading of the sugar beet rootlouse in northern Colorado. A comparison of the degree of infestation in all fields in those parts of the territorial sections where the narrowleafed cottonwood trees are most abundant and those parts where these trees are relatively few, results in some very interesting figures. All along the foothills and in the canons through which the streams 
which water the eastern plains make their way out of the mountains great numbers of narrow-leafed cottonwood trees are to be found. Normally these trees are very heavily infested with the gall form of Pemphigus betc. As we go eastward following the water courses, these trees gradually give place to the broad-leafed cottonwood, Populus occidentalis. Thus we find that in a strip 100 yards wide passing through the timber belt along the St. Vrain River at the west end of the river section there were 282 narrow-leafed cottonwoods and 6 broad-leafed ones. In a similar strip passing through the center of this section there were 429 narrow-leafed and 30 broad-leafed cottonwoods, while in a strip passing through the eastern portion of the section contained 185 narrow-leafed trees as against 134 broad-leafed ones.

Comparing all fields in the western half of this section with those in the eastern, we find that of those of the former portion 100 per cent have an infestation of over 70 per cent and of those of the latter but 97.5 per cent have an infestation of 70 per cent or above.

When we compare all fields within one-half mile of the river with all those more than this distance from it we find that those nearest the river and the narrow-leafed cottonwood trees in the timber belt along it have the heaviest infestation. Of the beets in those fields within the one-half mile limit, 87.07 per cent were above 90 per cent infested while of those in the fields outside of the one-half mile limit but $\mathbf{7 6 . 7 5}$ per cent were infested to a like degree.

An examination of the central section of the Longmont territory brings out the relation of the winter host and the infestation still more strongly than the preceding.

In the western half of this territory there are 244 host trees and in the eastern half but 25 . The per cent of all fields in the two halves of this section which have an infestation of over 70 per cent was 46.6 for the western and 35.7 for the eastern half. If we divide this section into halves by drawing a line from east to west, we find that the per cent of fields with an infestation of over 70 per cent is 56.6 for the north and 34.2 for the south half. There are 187 narrow-leafed trees in the north half and but 82 in the south. Now if we place all fields in this territory into two groups, one including all fields within one-half mile of narrow-leafed cottonwoods and the other including all fields at a greater distance from these trees, we find that of those within the one-half mile limit 46.42 per cent have an infestation of over 70 per cent while of those outside this limit but 36.95 per cent are infested to this degree.

Likewise in the eastern section 69.7 per cent of all fields in the west half, with 571 narrow-leafed trees, have an infestation of over 80 per 
cent while of those in the east half where there are but 22 narrow-leafed trees, 65.96 per cent have a like infestation.

In the north half of this territory there are 156 narrow-leafed cottonwood trees and in the south half 437 . Of the fields in these halves 78.6 per cent of those in the north and 84.6 per cent of those in the south half have an infestation of over 70 per cent.

If we compare all fields within one-half mile of narrow-leafed trees with all those from one-half to three-fourths and all over three-fourths mile of these trees we find 78.57 per cent, 60 per cent and 54.76 per cent respectively of the fields in the three zones have an infestation of over 80 per cent.

In making similar comparisons in the Eaton territory we find the same higher degree of infestation in fields within one-half mile of narrow-leafed cottonwood trees.

We also find that the western halves of both the north and south sections of this territory carry a heavier infestation than the eastern halves. In these sections it cannot be due to trees within the territories, as the northern section is nearly treeless and contains but one narrow-leafed cottonwood which is near the southwest corner of the section.

The south section has 46 trees of this species, 41 of which are in the southwest corner and five near the southeast corner. When the survey was made no galls of Pemphigus betee were found on any of these trees, most of which were small second growth stock or sprouts coming up about stumps of larger trees which had been cut down the year previous.

The heavy infestation of the west as compared with the eastern portion of these sections suggests the effect of the wind which is no doubt an active factor in the dissemination of the beet root-louse. Just how far the beet root-louse is carried by the wind has not been determined. During early summer, while the heaviest migration of this insect from the winter host is taking place, the prevailing winds of northern Colorado are westerly. It does not seem unreasonable that these insects might easily be carried from the mountains, many miles out on to the prairies by these winds.

West of the northern section of the Eaton territory there are several miles of practically treeless, unirrigated land. The Cache La Poudre River passes just southwest of the southern section of this territory. Along this stream there is a timber belt of varying width within which there are some narrow-leafed cottonwoods. It is probable that the infestation of the Eaton territory comes largely from these trees if not from the mountains.

This survey has been continued during the present summer in the 
Longmont territory over an area of 161,280 acres and in the Sterling territory, which is in the northeast corner of the state on the South Platte River. This latter territory covers an area of 38,400 acres. It is hoped that when the results of this study are worked up some valuable information will be secured.

\section{THE PINK BOLLWORM (GELECHIA GOSSYPIELLA) IN EGYPT}

By H. A. BAlLov, M. Sc., Entomologist on the Staff of the Imperial Department of Agriculture for the West Indies

Seconded for temporary service in Egypt by permission of the Colonial Office

\section{Native Home and Distribution}

The pink bollworm appears to be a native of India and the southern Asiatic region. It was introduced into Egypt in badly ginned cotton lint. The importation of cotton from India into Egypt occurred between the years 1903 and 1913 . The following table shows the amount of cotton so imported:-

\begin{tabular}{|c|c|c|c|}
\hline Year & $\begin{array}{c}\text { Quantity } \\
\text { in Kilograms }\end{array}$ & Year & $\begin{array}{c}\text { Quantity } \\
\text { in Kilograms }\end{array}$ \\
\hline 1903 & 20,510 & 1909 & 31,206 \\
\hline 1904 & 25,827 & 1910 & 13,353 \\
\hline 1905 & 9,150 & 1911 & $\ldots \ldots *$ \\
\hline $\begin{array}{l}1906 \\
\end{array}$ & 81,240 & 1912 & 10,998 \\
\hline 1907 & 162,000 & 1913 & 89,995 \\
\hline 1908 & 21,460 & & \\
\hline
\end{tabular}

It was found in 1913 that a very considerable number of cotton seeds occurred in this cotton and that in these seeds considerable numbers of pink bollworms were found.

Since that time cotton seed from Egypt has been imported into Brazil and Mexico and as a result pink bollworm is now established in those countries.

At the present time the pink bollworm is known to occur in: AsiaIndia, Ceylon, Burmah, Straits Settlements, The Pacific Islands-The Philippines and Hawaiian Islands. Africa-Egypt, Sudan, East and West Africa, Nigeria and Zanzibar. In the Western Hemisphere the pink bollworm now occurs in Mexico and Brazil where it has recently become established as a result of the introduction of Egyptian cotton seed for planting.

\section{Food Plants}

In Egypt the pink bollworm is known to attack cotton of all varieties, teel or Indian hemp (Hibiscus cannabinus), bahmia or okra (Hibiscus 